\section{Sodium Regulation in the Blood of Parr and Smolt Stages of the Atlantic Salmon}

The sea-ward migration of the salmon (Salmo salar) which coincides with the parr-smolt transformation, involves the solution of important osmotic and mineral regulation problems by the fish. The lack of tolerance for salt water at the parr stage has been noted previously ${ }^{1}$. However, neither the capacities for mineral regulation of this stage nor their probable shift in the smolt have been subjected to an analysis, made more desirable by the fact that, like the endocrinological changes which occur at the same time ${ }^{2}$, they may be causally connected with migration itself $^{3}$.

Working at Laholm in the South of Sweden, we were able to investigate the regulation capacities for sodium of the young salmon in the parr stage as well as those of one-and two-year-old smolts reared under the same conditions in running water of the Lagan stream. Moreover, an opportunity arose which allowed us to conduct simultaneously similar experiments on individuals migrating downstream captured in the nearby Ätran stream in water having the same temperature $\left(6.3^{\circ} \mathrm{C}.\right)$. The blood-plasma of the animals, in $10 \lambda$ quantities, was subjected to microsodium analysis by means of flame spectrophotometry.

When abruptly transferred from fresh water to full sea-water (at the same temperature) none of the twoyear-old parrs survived for more than 26 hours. The living individuals analysed showed, as time went on, a rapidly rising sodium concentration in their blood. None of the individuals in the smolt stage, whether oneor two-year-old, died when submitted to the same abrupt change in salinity. The sodium concentration in their blood remained nearly constant in the days following the transfer. The smolts trapped on their down-stream migration still showed parr characteristics to a certain degree. Two out of ten died within 18 hours when abruptly transferred to sea-water. A further threa showed great distress. The sodium-level in the blocd of the surviving individuals increased strongly, the normal level being however restored 4-5 days later. Obviously they were in a transitory condition which also includes the sodium regulation of their blood. Similar results were obtained in other experiments.

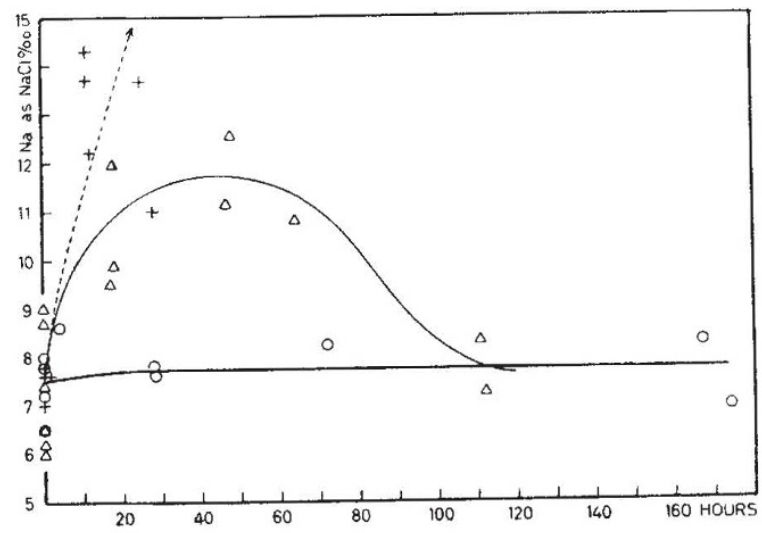

Fig. 1. Variations of the sodium concentration of the blood after abrupt transfer from fresh water $\left(6 \cdot 3^{\circ} \mathrm{C}\right.$ ) to full sea water $\left(6 \cdot 3^{\circ} \mathrm{C}\right)$. smolts caught on downstream migration.
It has been observed in Hölle during the parr-smolt transformation that a large percentage of the smolts die when kept back in fresh water. The osmotic capacities of the smolts in fresh water seem to be impaired at the time when the parr-smolt transformation occurs. Wide individual variation in the sodium level of wild smolts in fresh water is obvious from Fig. 1. Details of this and previous work will be published elsewhere.

\section{H. J. KOCH \\ J. C. Evans}

Laboratory of Zoophysiology of the Lniversity, Louvain, Belgium.

May 19.

\section{E. Bergströin}

Migratory Fish Committee,

Salmon Research Laboratory, Hölle, Bispfors, Sweden.

1 Fage, 1., Bull. Inst. Océan. Monaco, 225, 1 (1912). Jones, J. W., Salnwon and Trout May., 119, 33 (1947). Huntsman, A. (t., and Hoar, W. \&. J. Fish Res. Bd. Canada, 4, 409, (1939).

${ }^{2}$ Fontaine, M., Biol. Kec., 29, 390 (1954). Fontaine, M., and olivereat, M. J. Physiol., 49, $174(1957)$

Fontaine, M., and Callamand, O., Bull. Mus. Hist. Nat., XV, 373 (1943) Koch, H. J., Ann. Soc. Roy."Zool. Belg., LXXIII, 5 (1942). Koch, H. J., and Heuts, M. J., Ann. Soc. Roy. Zool. Belg., LXXIII, 165 (1942). Koch, H. J, and Heuts, M.J., Arch. Int. Phys., LIII, 25

(1943). Fontaine, $\mathrm{X}$, and Koch, H, J J Physiol, 42, 287 (1950).

\section{Release by Flight Exercise of a Chemotropic Response from Photopositive Domination in a Scolytid Beetle}

ONE of the remarkable features of barkbeetles and ambrosia beetles is their power of discovery and selection of host tree material. From a mass of varied material in a forest they select and bore into specific parts of specific trees, usually only when those trees are under stress of age, environment, injury or encroaching death. Certain of the ambrosia beetles show a strong preference for logs that have 'ripened' for a period of some weeks or months after being felled. The species, Trypodendron (Xyloterus) lineatum Oliver (Scolytidae), is one of these.

The present communication is a preliminary report on an aspect of behaviour in $T$. lineatum that appears to be a key to elucidating the host-finding process in this insect and perhaps other Scolytids.

Trypodendron, on issuing from its overwintering quarters in the litter of the forest floor ${ }^{1}$, takes to flight and arrives in large numbers at partly 'ripened' logs of coniferous species. It appears to accomplish this result without expending time and effort on unsuitable material. Theoretical considerations of the known physiology of trees and behaviour of insects, suggested that odour must be examined as a possible clue that these beetles use in host discovery and selection. Studies were undertaken to determine whether they show any kinetic or directional response to airborne odours from attractive wood. Many failures under illuminated conditions to detect decisive or even statistical differences of activity in beetles exposed to wood odour, led to the conclusion that the failure lay not in the environmental conditons, nor in the method of observation, but in the photic orientation responses that dominated behaviour at a particular time. This conclusion led to the search for a natural 